\title{
Relationships of Generalized and Regional Adiposity to Insulin Sensitivity in Men
}

\author{
Nicola Abate, ${ }^{\star 5}$ Abhimanyu Garg, ${ }^{\star 5}$ Ronald M. Peshock, ' James Stray-Gundersen, ${ }^{\star *}$ and Scott M. Grundy *\$\$ \\ ${ }^{*}$ Center for Human Nutrition and the Departments of ${ }^{\ddagger}$ Clinical Nutrition, ${ }^{8}$ Internal Medicine, "Biochemistry, 'Radiology, and \\ **Orthopedic Surgery and Physiology, University of Texas Southwestern Medical Center at Dallas, Dallas, Texas $75235-9052$
}

\begin{abstract}
The relative impacts of regional and generalized adiposity on insulin sensitivity have not been fully defined. Therefore, we investigated the relationship of insulin sensitivity (measured using hyperinsulinemic, euglycemic clamp technique with $\left[3-{ }^{3} \mathbf{H}\right]$ glucose turnover) to total body adiposity (determined by hydrodensitometry) and regional adiposity. The latter was assessed by determining subcutaneous abdominal, intraperitoneal, and retroperitoneal fat masses (using magnetic resonance imaging) and the sum of truncal and peripheral skinfold thicknesses. 39 healthy middle-aged men with a wide range of adiposity were studied. Overall, the intraperitoneal and retroperitoneal fat constituted only 11 and $7 \%$ of the total body fat. Glucose disposal rate $\left(\boldsymbol{R}_{\mathrm{d}}\right)$ and residual hepatic glucose output (rHGO) values during the $40 \mathrm{mU} / \mathrm{m}^{2} \cdot \mathrm{min}$ insulin infusion correlated significantly with total body fat $(r=-0.61$ and 0.50 , respectively $)$, subcutaneous abdominal fat $(r=-0.62$ and 0.50 , respectively), sum of truncal skinfold thickness $(r=-0.72$ and 0.57 , respectively), and intraperitoneal fat $(r=-0.51$ and 0.44 , respectively) but not to retroperitoneal fat. After adjusting for total body fat, the $R_{d}$ and rHGO values showed the highest correlation with the sum of truncal skinfold thickness (partial $r=-0.40$ and 0.33 , respectively). We conclude that subcutaneous truncal fat plays a major role in obesity-related insulin resistance in men, whereas intraperitoneal fat and retroperitoneal fat have a lesser role. (J. Clin. Invest. 1995. 96:88-98.) Key words: obesity • insulin resistance • fat distribution • skinfolds • magnetic resonance imaging
\end{abstract}

\section{Introduction}

Obesity is known to be accompanied by several metabolic complications and has been increasingly recognized as a risk factor for chronic diseases such as non-insulin-dependent diabetes mellitus (NIDDM), ${ }^{1}$ dyslipidemia, and atherosclerotic cardio-

Address correspondence to Abhimanyu Garg, M.D., Center for Human Nutrition, UT Southwestern Medical Center at Dallas, 5323 Harry Hines Blvd., Dallas, TX 75235-9052. Phone: 214-648-2895; FAX: 214-6484837.

Received for publication 23 January 1995 and accepted in revised form 31 March 1995.

1. Abbreviations used in this paper: BMI, body mass index; HGO, hepatic glucose output; MRI, magnetic resonance imaging; NIDDM, non-insulin-dependent diabetes mellitus; $\boldsymbol{R}_{\mathrm{a}}$, rate of glucose appearance; $R_{\mathrm{d}}$, glucose disposal rate; rHGO, residual hepatic glucose output; $\mathrm{W} / \mathrm{H}$, waist to hip circumference ratio.

J. Clin. Invest.

(C) The American Society for Clinical Investigation, Inc.

0021-9738/95/07/0088/11 $\$ 2.00$

Volume 96, July 1995, 88-98 vascular diseases (1-6). Recent studies indicate that obesityinduced insulin resistance may be an important factor contributing to these complications (7-9). In general, the risk of developing complications is proportional to the total amount of excess fat present in the body. However, there is growing evidence that the location, or distribution, of excess body fat may incrementally influence the severity of complications. Early investigations by Vague (10) and subsequent cross-sectional (1117) and longitudinal studies (18-23) have shown that excess accumulation of fat in the upper body or truncal region, particularly in the abdominal region, is a better predictor of morbidity than total body obesity.

The concept that truncal adiposity has a more deleterious effect on health is supported by in vitro studies of metabolism of adipocytes from different anatomical regions. Although no consistent differences have been noted in basal rates of lipolysis and antilipolytic effect of insulin in adipose tissue from various anatomical sites (24-27), catecholamine-induced lipolysis has been reported to be uniformly higher in adipose tissue from omentum or mesentery (intraperitoneal region) than that from subcutaneous abdominal region $(24,28,29)$ which in turn shows higher lipolysis rates than do gluteal and femoral adipose tissues (30). Particular attention has been paid to intraperitoneal adipose tissue also because of its venous drainage into the portal system and directly into liver, which raises the theoretical possibility that excess free fatty acids (FFA) and glycerol released from this location could have unique adverse effects on hepatic metabolism (31).

In spite of clinical and epidemiologic observations and in vitro data supporting the concept that the distribution as well as the amount of body fat influence the metabolic impact of obesity, views on the effects of regional excess of fat are not uniform. This lack of agreement stems in part from uncertainty engendered by the lack of methodology for accurate determination of the mass of adipose tissue in different regions. Particularly difficult to measure is the quantity of the potentially important intraperitoneal fat. Recently, we reported the validation of a method using magnetic resonance imaging (MRI) for the precise measurement of actual masses of abdominal adipose tissue regions, i.e., intraperitoneal, retroperitoneal, and subcutaneous abdominal adipose tissue (32). Using this technique, in the present study, along with anthropometric measurements of body fat, we investigated the relationship of insulin sensitivity to overall and regional obesity, with special attention to abdominal obesity, in nondiabetic male subjects. Another aim of the study was to determine the interrelationships between masses of different regions of abdominal adipose tissue and other measurements of body fat.

\section{Methods}

Subjects and study design. 39 healthy men (30 Caucasians, 4 AfricanAmericans, 2 Mexican-Americans, 2 Asians, and 1 Egyptian) were 
recruited for this study by public advertisement. These subjects had a mean (SD) age of 47 (11) yr and a mean body mass index (BMI) of $28.5(7.7) \mathrm{kg} / \mathrm{m}^{2}$. The total body fat content ranged from 8.6 to $41.2 \%$ of the total body mass. Patients with diabetes mellitus and other endocrine disorders, coronary artery disease, liver function tests abnormalities, and those on any form of therapy were excluded. The study was approved by the University of Texas Southwestern Medical Center Institutional Review Board, and all subjects gave informed written consent for participating. After collecting information on medical history and screening for hematological and blood chemistry abnormalities, each subject was admitted for a period of $3 \mathrm{~d}$ at the General Clinical Research Center of the University of Texas Southwestern Medical Center at Dallas. All subjects were provided with an isocaloric diet during the admission period.

Oral glucose tolerance test. A standard oral glucose tolerance test with $75 \mathrm{~g}$ of glucose (Tru-Glu ${ }^{100}$; Fisher Scientific, Pittsburgh, PA) was conducted after $12 \mathrm{~h}$ of overnight fasting on the first day of admission. An intravenous catheter was placed in a forearm vein and blood was collected for determination of glucose and insulin concentrations at $-30,-15$, and $0 \mathrm{~min}$ before glucose administration and at $30-\mathrm{min}$ intervals thereafter for $180 \mathrm{~min}$.

Anthropometric measurements. Height and weight were measured by standard procedures. Waist and hip circumferences were measured, using a flexible measuring tape with a tension caliper at the extremity (Gulick-Creative Health Product, Inc., Plymouth, MI), midway between the xiphoid and the umbilicus during the midinspiratory phase and at the maximum circumference in the hip area, respectively. The waist-tohip circumference $(\mathrm{W} / \mathrm{H})$ ratio was calculated for each subject. Skinfold thickness was measured at nine different anatomical sites (subscapular [diagonal and vertical], chest, midaxillary, abdominal [horizontal and vertical], suprailiac [diagonal and vertical], triceps, biceps, thigh, and calf) using a Lange skinfold caliper (Cambridge Scientific Industries Inc., Cambridge, MD). The means of three repeat measurements at each site were used for calculations. The horizontal/diagonal and vertical measurements of the subscapular, suprailiac, and abdominal skinfolds were averaged. The sum of truncal skinfold thickness was calculated by adding the skinfold thicknesses of subscapular, midaxillary, chest, abdomen, and suprailiac sites and the sum of peripheral skinfold thickness by adding skinfold thicknesses of triceps, biceps, thigh, and calf regions.

Body composition was studied by determination of body density using a volumeter (Whitmore Enterprises, San Antonio, TX). Each subject was submerged in water up to the chin in a seated position. Then he was given $3,000 \mathrm{ml}$ of gas to rebreathe ( $45 \%$ oxygen, $10 \%$ helium, and $45 \%$ nitrogen) and went completely underwater. Total volume displacement was measured to the nearest $50 \mathrm{ml}$. After resurfacing, helium concentration was measured in the exhaled gas by mass spectrometry (model 1100; Perkin-Elmer Corp., St. Louis, MO). Total submerged gas volume was calculated by the formula: total gas volume $(\mathrm{ml})=300 \mathrm{ml} \mathrm{He} /$ final $[\mathrm{He}]+100 \mathrm{ml}$ (for abdominal gas). Total gas volume was subtracted from total displacement volume to give total body volume. Total body mass $(\mathrm{kg})$, measured to the nearest $0.1 \mathrm{~kg}$, was divided by body volume to obtain body density. Siri's equation (33) was used to estimate percentage of total body fat, lean body mass, and total fat mass.

MRI. The MRI studies were performed using a $0.35 \mathrm{~T}$ imaging device (Toshiba America MRI, Inc., South San Francisco, CA) with a contiguous axial 10-mm slices. The MRI studies used a ' $\tau$ ' (tau) 1 weighted spin echo sequence with $300-\mathrm{ms}$ repetition time and $15 \mathrm{~ms}$ echo time, one-half excitation for all acquisitions. Seven slices were obtained for each acquisition sequence. The duration of each acquisition was $36 \mathrm{~s}$. Three to four acquisitions were necessary to cover the entire abdomen. Data from all images were acquired on a $256 \times 192$ matrix within a $51.2 \times 28.4 \mathrm{~cm}$ field of view, $2 \times 2 \times 10 \mathrm{~mm}^{3}$ voxel, giving a $40-\mathrm{mm}^{3}$ pixel volume. Data from all images were stored on magnetic tapes and transferred to a Toshiba 0.35 computer (Toshiba Inc., South San Francisco, CA) for analysis. Fat volume was measured in each slice by mapping subcutaneous and intraabdominal adipose tissue compart- ments on the computer screen using a track-ball. Intraabdominal adipose tissue was distinguished and separated into intraperitoneal and retroperitoneal adipose tissue compartments using anatomical points, such as ascending and descending colon, aorta, and inferior vena cava. The number of pixels counted in each compartment was converted into a volume (multiplying the number of pixels by $0.04 \mathrm{~cm}^{3}$ ). Assuming that adipose tissue is composed of $84.67 \%$ fat, $12.67 \%$ water, and $2.66 \%$ proteins (34), the density of adipose tissue was calculated to be 0.9196 $\mathrm{kg} /$ liter. Therefore, adipose tissue mass was calculated in kilograms for each 10-mm-thick slice. The masses obtained for each slice were summed to calculate the total adipose tissue mass for each identified compartment (subcutaneous abdominal, intraperitoneal, and retroperitoneal). This procedure has been validated recently in human cadavers (32).

Euglycemic, hyperinsulinemic, glucose clamp study. Clamp studies were conducted on the last day of admission after an overnight fast. A prime-continuous infusion of regular insulin (Humulin; Squibb-Novo, Princeton, NJ) was given intravenously, at a rate of $20 \mathrm{mU} / \mathrm{m}^{2} \cdot \mathrm{min}$, from time 0 to $120 \mathrm{~min}$ (low-dose insulin infusion). The insulin infusion rate was increased to $40 \mathrm{mU} / \mathrm{m}^{2} \cdot \min$ from time 120 to $210 \mathrm{~min}$ (highdose insulin infusion). Blood samples were obtained every $5 \mathrm{~min}$ from a catheter placed retrograde in a dorsal vein of a hand kept in a radiant warmer at $70^{\circ} \mathrm{C}$ to arterialize venous blood. Dextrose solution (20\%) was infused intravenously to maintain plasma glucose at the fasting levels throughout the clamp procedure, according to the method of DeFronzo et al. (35). To study glucose turnover, a primed-continuous intravenous infusion of $\left[3-{ }^{3} \mathrm{H}\right]$ glucose (DuPont-New England Nuclear, Boston, MA) was started at a rate of $2.36 \mathrm{nCi} \cdot \mathrm{kg}^{-1} \cdot \mathrm{min}^{-1}$ at $120 \mathrm{~min}$ before the initiation of insulin infusion $(-120 \mathrm{~min})$ and was continued throughout the duration of the clamp. To minimize the physiologically unacceptable negative values of hepatic glucose output (HGO) during the hyperinsulinemic phase of the study, the $20 \%$ dextrose solution was "spiked" with $\left[3-{ }^{3} \mathrm{H}\right]$ glucose to maintain constant specific activity according to Finegood et al. (36). Blood samples for measurement of glucose, insulin, and $\left[3-{ }^{3} \mathrm{H}\right]$ glucose specific activity were collected at 10-min intervals from -40 to $0 \mathrm{~min}$, from 80 to $120 \mathrm{~min}$, and from 170 to 210 min during the study.

The rate of glucose appearance $\left(R_{\mathrm{a}}\right)$ in plasma was calculated by measuring specific activity of $\left[3-{ }^{3} \mathrm{H}\right]$ glucose in the plasma using the one compartment model described by Steele et al. (37) and modified, for labeled variable glucose infusion, by Finegood et al. (36), assuming volume of distribution of $210 \mathrm{ml} / \mathrm{kg} \mathrm{(38)}$. Endogenous glucose production, or HGO during the clamp, was calculated as the difference between $R_{\mathrm{a}}$ and glucose infusion rate for the time interval, and negative values, if any, were assumed to be equal to zero. The rate of glucose disposal $\left(R_{\mathrm{d}}\right)$ was calculated from the $R_{\mathrm{a}}$ using space correction. The data for HGO and $R_{\mathrm{d}}$ are presented in milligrams per minute per kilogram of lean body mass.

Biochemical analyses. Plasma glucose concentrations were assayed by glucose oxidase method (Beckman Glucose Analyzer; Beckman Instruments, Fullerton, CA). The specific activity of glucose was determined from the plasma samples deproteinized by barium hydroxide and zinc sulphate precipitation, according to Meneilly et al. (39). Plasma insulin levels were determined by modification (40) of the radioimmunoassay described by Yalow and Berson (41).

Calculations and statistical analyses. All data were analyzed using statistical programs (BMDP and CLINFO). Two types of analyses were carried out. First, the 39 subjects were divided into three groups according to tertiles of total body fat, namely, lean, intermediate, and obese groups; and second, for all subjects together, various correlations were carried out. One-way analysis of variance (ANOVA) was performed to compare parameters of interest among the three groups. To assess for significance of trends in the variables, orthogonal linear contrasts were included in the model. Two-sample $t$ tests with Bonferroni adjustment were used for multiple comparisons when the $F$ statistic from the ANOVA had a $P$ value $<0.05$. The Kruskal-Wallis test followed by Bonferroni-adjusted Wilcoxon rank sum test was used for comparing HGO values. MRI study could not be performed in three subjects due to excessive body weight and in another subject due to a technical 


\begin{tabular}{|c|c|c|c|c|}
\hline & $\begin{array}{l}\text { Lean group } \\
\quad(n=13)\end{array}$ & $\begin{array}{l}\text { Intermediate group } \\
\quad(n=13)\end{array}$ & $\begin{array}{l}\text { Obese group } \\
\quad(n=13)\end{array}$ & $\begin{array}{c}P \text { value } \\
\text { (ANOVA) }\end{array}$ \\
\hline Age $(y r)$ & $\begin{array}{r}45.1 \pm 7.8 \\
(22-70)\end{array}$ & $\begin{array}{c}47.8 \pm 13.1 \\
(35-68)\end{array}$ & $\begin{array}{c}48.0 \pm 10.9 \\
(35-59)\end{array}$ & 0.74 \\
\hline BMI $\left(\mathrm{kg} / \mathrm{m}^{2}\right)$ & $\begin{array}{c}22.9 \pm 2.1 \\
(19.4-27.0)\end{array}$ & $\begin{array}{c}25.6 \pm 2.7 \\
(21.0-29.5)\end{array}$ & $\begin{array}{c}36.8 \pm 7.7^{* \ddagger} \\
(24.7-47.0)\end{array}$ & $<0.0001$ \\
\hline W/H ratio & $\begin{array}{c}0.91 \pm 0.03 \\
(0.86-0.96)\end{array}$ & $\begin{array}{c}0.94 \pm 0.06 \\
(0.84-1.03)\end{array}$ & $\begin{array}{c}0.99 \pm 0.07 * \\
(0.87-1.13)\end{array}$ & 0.02 \\
\hline Lean body mass $(\mathrm{kg})$ & $\begin{array}{c}60.4 \pm 10.2 \\
(46-82)\end{array}$ & $\begin{array}{r}62.6 \pm 8.9 \\
(48-75)\end{array}$ & $\begin{array}{l}78.8 \pm 12.0^{* \ddagger} \\
(56-97)\end{array}$ & $<0.0001$ \\
\hline Total body fat (percentage of body mass) & $\begin{array}{l}14.7 \pm 2.5 \\
(8.6-17.4)\end{array}$ & $\begin{array}{c}21.1 \pm 2.3^{*} \\
(17.6-24.2)\end{array}$ & $\begin{array}{c}31.9 \pm 5.6^{* \ddagger} \\
(26.4-41.2)\end{array}$ & $<0.0001$ \\
\hline Sum of truncal skinfold thickness (mm) & $\begin{array}{c}75.2 \pm 17.0 \\
(46.5-111.8)\end{array}$ & $\begin{array}{l}100.1 \pm 27.3^{8} \\
(53.5-147.4)\end{array}$ & $\begin{array}{c}186.9 \pm 56.5^{* \ddagger} \\
(73.6-267.4)\end{array}$ & $<0.0001$ \\
\hline Sum of peripheral skinfold thickness (mm) & $\begin{array}{c}30.9 \pm 8.8 \\
(20.6-48.4)\end{array}$ & $\begin{array}{c}40.0 \pm 12.5 \\
(20.2-58.0)\end{array}$ & $\begin{array}{c}90.6 \pm 44.3^{* \ddagger} \\
(34.0-200.4)\end{array}$ & $<0.0001$ \\
\hline
\end{tabular}

Mean \pm SD (range). ${ }^{*} P<0.01,{ }^{8} P<0.05$ vs. lean group (Bonferroni-adjusted); ${ }^{\ddagger} P<0.01$ vs. intermediate group (Bonferroni-adjusted).

problem with storage of images. However, they were not excluded from the analyses.

Pearson product-moment correlation coefficients $(r)$ and partial correlations adjusting for total body fat were computed to measure associations between variables. Logarithmic transformation of the variables was used to compute correlation coefficients where the relationships were not linear. For HGO during the hyperinsulinemic phase of the study, Spearman rank correlations and partial correlations were computed. Results are presented as mean \pm SD unless otherwise stated.

\section{Results}

The characteristics of the three groups of subjects are shown in Table I. Ages were similar in all groups. The lean group had relatively low mean values for total body fat, lean body mass, $\mathrm{BMI}, \mathrm{W} / \mathrm{H}$ ratio, and the sum of truncal and peripheral skinfold thickness. The intermediate group had values that approximate the average for middle-aged American men (42), whereas for the obese group the parameters were abnormally high. Based on the National Diabetes Data Group criteria (43), the lean, intermediate, and obese groups had 3,1, and 2 subjects with impaired glucose tolerance, respectively. None of the subjects had diabetes mellitus. During the oral glucose tolerance test, the median values for area under the curve for the plasma glucose in the lean, intermediate, and obese groups were $21.8,19.4$, and $20.8 \mathrm{mmol} \cdot \mathrm{h} /$ liter, respectively $(P=0.13)$, and for plasma insulin $849,1,148$, and $1,624 \mathrm{pmol} \cdot \mathrm{h} /$ liter, respectively $(P$ $=0.16)$.

Total body fat and its distribution in the three abdominal compartments is compared among the three groups in Table II. Fig. 1 shows the relationships of fat content (kilograms) in the different abdominal compartments with the total body fat mass. A significant correlation was found between total fat mass and the contents of each compartment. In all groups, the largest amount of abdominal fat was present in the subcutaneous compartment; it averaged about twice that of intraperitoneal fat. Although subcutaneous abdominal fat and intraperitoneal fat increased progressively as percentage of total body mass with increasing total fat, their values as percentages of total body fat remained approximately constant (Table II). There was a significant positive correlation $(r=0.72 ; P<0.0001)$ between masses of subcutaneous abdominal fat and intraperitoneal fat (Fig. 2). In the lean group, retroperitoneal fat mass was $73 \%$ of that of intraperitoneal fat, but retroperitoneal fat failed to increase in proportion to subcutaneous abdominal and intraperitoneal fat with increasing obesity (Table II).

Skinfold thicknesses at all sites similarly showed a progressive increase with increasing percent body fat (data not shown). The ratio of the sum of truncal-to-peripheral skinfold thickness was similar in the three study groups (mean $\pm S D ; 2.50 \pm 0.44$, $2.62 \pm 0.77$, and $2.23 \pm 0.57$, in the lean, intermediate, and obese groups, respectively, $P=0.22$ ), indicating that fat distribution in the various subcutaneous regions did not change significantly with increasing total body adiposity.

Table III summarizes the relationships between variables of generalized and regional adiposity. With the exception of retroperitoneal adipose tissue mass, which was significantly correlated only with $\mathrm{W} / \mathrm{H}$ ratio and intraperitoneal fat mass, all other variables were highly intercorrelated. Increasing total body fat was associated with a progressive increase in the subcutaneous abdominal fat mass and intraperitoneal fat mass. Significant relationships were also observed between $\mathrm{W} / \mathrm{H}$ ratio and total body fat and intraperitoneal fat masses but not with subcutaneous abdominal fat mass.

Table IV presents the results of the euglycemic, hyperinsulinemic glucose clamp studies. Plasma glucose levels were similar in the three groups during both fasting and the hyperinsulinemic periods. Fasting insulin levels, however, showed a trend toward higher values in the intermediate group, and, in the obese group, they were substantially higher than those of the lean group. At both low-dose and high-dose insulin infusion rates, $R_{\mathrm{d}}$ values were significantly lower in the obese group compared with the lean group. The reduction of $R_{\mathrm{d}}$ values with increasing generalized adiposity across the three groups was significant for both the low-dose and high-dose insulin infusions ( $P=0.017, P=0.0004$, respectively $)$.

In addition to the data analysis of Table IV, Fig. 3 depicts the relationships between generalized or regional adiposity and $R_{\mathrm{d}}$ values at high-dose insulin infusion. Similar results were obtained with low-dose insulin infusion (data not shown). $R_{\mathrm{d}}$ values were significantly correlated with total body fat mass 
Table II. Distribution of Fat in Various Abdominal Adipose Tissue Regions for the Three Study Groups

\begin{tabular}{|c|c|c|c|c|}
\hline & Lean group & Intermediate group & Obese group & $P$ value (ANOVA) \\
\hline \multicolumn{5}{|l|}{ Total abdominal fat } \\
\hline (kg) & $4.3 \pm 1.5$ & $7.0 \pm 2.7^{*}$ & $12.3 \pm 3.9^{* 5}$ & $<0.0001$ \\
\hline (percentage of total body mass) & $5.9 \pm 1.4$ & $8.7 \pm 2.5^{*}$ & $10.8 \pm 2.4^{* 8}$ & $<0.0001$ \\
\hline (percentage of total body fat) & $41.0 \pm 7.7$ & $41.3 \pm 10.1$ & $34.7 \pm 6.1$ & 0.11 \\
\hline \multicolumn{5}{|l|}{ Subcutaneous abdominal fat } \\
\hline$(\mathrm{kg})$ & $2.4 \pm 0.8$ & $3.6 \pm 1.5$ & $7.2 \pm 2.7^{* 5}$ & $<0.0001$ \\
\hline (percentage of total body mass) & $3.3 \pm 0.9$ & $4.4 \pm 1.5^{\| \prime}$ & $6.3 \pm 1.8^{* 5}$ & 0.0002 \\
\hline (percentage of total body fat) & $22.8 \pm 5.9$ & $21.0 \pm 6.9$ & $20.3 \pm 5.6$ & 0.63 \\
\hline \multicolumn{5}{|l|}{ Intraperitoneal fat } \\
\hline$(\mathrm{kg})$ & $1.1 \pm 0.5$ & $2.3 \pm 1.2 *$ & $3.5 \pm 1.7^{*}$ & 0.0005 \\
\hline (percentage of total body mass) & $1.5 \pm 0.5$ & $2.7 \pm 1.2^{11}$ & $3.1 \pm 1.3^{*}$ & 0.004 \\
\hline (percentage of total body fat) & $10.4 \pm 2.9$ & $12.9 \pm 4.7$ & $9.9 \pm 3.3$ & 0.12 \\
\hline \multicolumn{5}{|l|}{ Retroperitoneal fat } \\
\hline$(\mathrm{kg})$ & $0.8 \pm 0.3$ & $1.2 \pm 0.4^{*}$ & $1.6 \pm 0.5^{*}$ & 0.002 \\
\hline (percentage of total body mass) & $1.1 \pm 0.3$ & $1.5 \pm 0.4$ & $1.5 \pm 0.5$ & 0.08 \\
\hline (percentage of total body fat) & $7.8 \pm 1.9$ & $7.3 \pm 2.0$ & $4.6 \pm 1.5 * 1$ & 0.0003 \\
\hline
\end{tabular}

Mean \pm SD. ${ }^{*} P<0.01$, " $P<0.05$ vs. lean group (Bonferroni-adjusted); ${ }^{8} P<0.01,{ }^{1} P<0.05$ vs. intermediate group (Bonferroni-adjusted). Total abdominal fat represents the sum of subcutaneous abdominal, intraperitoneal, and retroperitoneal fat masses.

(expressed as percentage of body mass) (Fig. $3 \mathrm{~A}$ ); however, considerable individual variability was noted, particularly at lower body fat masses. Intraperitoneal fat mass also was correlated with $R_{\mathrm{d}}$ values, but the coefficient was somewhat less than that for total body fat (Fig. $3 C$ ). Retroperitoneal fat mass, however, showed no relationship to $R_{\mathrm{d}}$ values (Fig. $3 \mathrm{D}$ ). Subcutaneous abdominal fat mass correlated with $R_{\mathrm{d}}$ values to a similar degree as did total body fat (Fig. $3 B$ ), whereas an even stronger relationship was noted for the sum of truncal skinfold thickness (Fig. $4 A$ ). The sum of peripheral skinfold thickness was less highly correlated to $R_{\mathrm{d}}$ values $(r=-0.56, P=0.003)$.

An attempt was made to dissect the relative influence of regional adiposity and generalized adiposity by calculating partial correlations adjusting for total body fat (Table V). These analyses revealed a partial correlation with a $P$ value of 0.06 between subcutaneous abdominal fat and $R_{\mathrm{d}}$ value after adjustment for total body fat. Partial correlations for intraperitoneal fat and retroperitoneal fat were not statistically significant, but the partial correlation for the combination of subcutaneous abdominal and intraperitoneal fat reached statistical significance $(P=0.05)$. Furthermore, the highest partial correlation was found with the sum of truncal skinfold thickness $(P=0.01)$, whereas no trend was observed for the sum of peripheral skinfold thickness.

Finally, the relationships between regional adiposity and hepatic insulin sensitivity were examined. The relationships between various measures of adiposity and residual hepatic glucose output (rHGO) during the hyperinsulinemic phase, either as absolute values or as percent suppression of fasting values, were similar for both the low-dose and high-dose insulin infusions. Further, normalizing the HGO values with either total body mass or lean body mass also yielded similar results. Therefore, only the absolute values of the HGO in milligrams per minute per kilogram of lean body mass during the high-dose insulin infusion are presented and other data are not shown. As shown in Table V, fasting HGO was somewhat lower in the obese subjects but was suppressed less during the high-dose insulin infusion than the other two groups. Fig. 5 shows that total fat, subcutaneous abdominal fat, and intraperitoneal fat were highly correlated with rHGO values; no correlation was found for retroperitoneal fat. A significant correlation was also observed with the sum of truncal skinfold thickness and rHGO (Fig. $4 \mathrm{~B}$ ) but not with the sum of peripheral skinfold thickness (data not shown). Finally, partial correlation analysis, after adjustment for total body fat, suggested that the sum of subcutaneous abdominal and intraperitoneal fat as well as the sum of truncal skinfold thickness contribute independently to hepatic insulin sensitivity beyond that imparted by total body fat (Table VI). The relationships between $\boldsymbol{R}_{\mathrm{d}}$ values and $\mathrm{rHGO}$ and various parameters of generalized and regional adiposity were not affected by the racial composition or the age of the subjects.

\section{Discussion}

Excessive release of FFA and glycerol from adipocytes into the circulation in the obese state probably is responsible for the majority of adverse metabolic consequences of obesity, particularly, for insulin resistance (44-47). Since all adipose tissue can release FFA, the excess body fat in obese persons should give rise to high plasma FFA levels and turnover; these responses, in fact, have been reported (48-50). However, the concept has arisen that an excess of adipose tissue in the abdominal region can especially enhance peripheral insulin resistance. This would be possible only if this particular adipose tissue site is either more metabolically active than others or if the sheer mass of adipose tissue accumulated in this region contributes significantly more to plasma FFA levels than does adipose tissue in the rest of the body. Several epidemiologic and clinical studies $(51-53)$ lend support to the concept of increased morbidity caused by a regional excess of adipose tissue. In particular, some individuals seem to be unusually susceptible to accumulate fat in the abdomen or trunk (54) and to develop insulin resistance $(17,19)$. The $\mathrm{W} / \mathrm{H}$ ratio has been used to distinguish people having predominantly abdominal (or truncal) obesity from those with mainly peripheral obesity. Individuals having rela- 

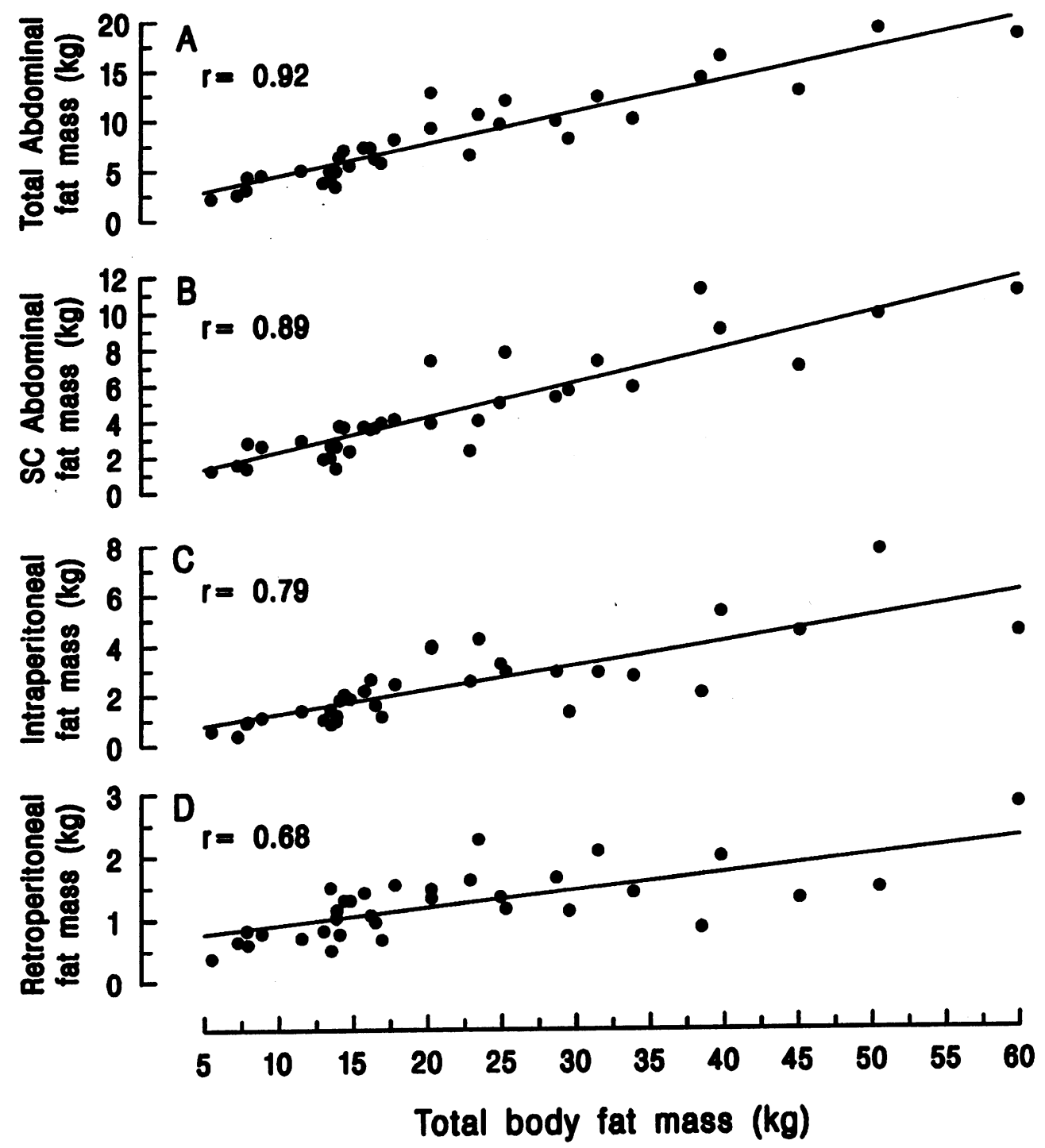

Figure 1. The relationships of total body fat mass and total abdominal $(A)$, subcutaneous $(\mathrm{SC})$ abdominal $(B)$, intraperitoneal $(C)$, and retroperitoneal $(D)$ fat masses. $r$ indicates Pearson correlation coefficient.

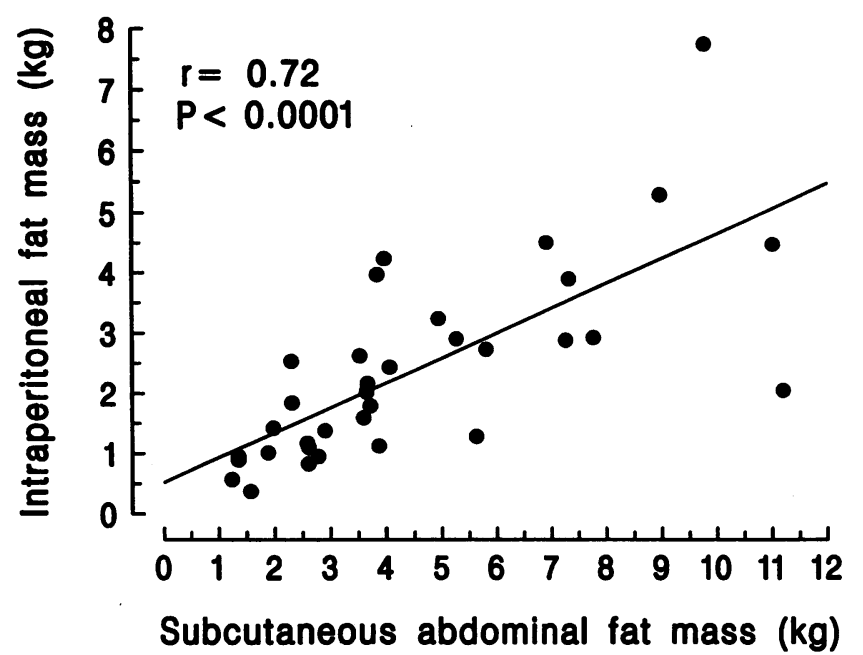

Figure 2. The relationship of subcutaneous abdominal fat mass and intraperitoneal fat mass. $r$ indicates Pearson correlation coefficient. tively high $\mathrm{W} / \mathrm{H}$ ratios have been reported to be more likely to have the metabolic complications of obesity $(11-23)$.

In accord with this concept, Jensen et al. (55) reported that obese women with high $\mathrm{W} / \mathrm{H}$ ratios had higher FFA levels and turnover rates than obese women with low $\mathrm{W} / \mathrm{H}$ ratios. The $\mathrm{W} / \mathrm{H}$ ratios, however, yield only rough estimates of fat about the abdomen (56) and clearly do not provide a quantitative measurement of intraabdominal fat. Some investigators have used computerized tomography or MRI techniques to study intraabdominal adiposity and its relationship with metabolic complications (57-59). These studies, however, have used a single transverse slice or a few slices of abdomen to study relative areas of intraabdominal and subcutaneous abdominal fat and do not provide absolute fat masses; thus research in this field has been hampered by a lack of methodology for the precise quantitation of mass of various compartments of abdominal adipose tissue. Of particular importance, in the previous studies, no distinction was made between intraperitoneal and retroperitoneal fat; since only the former drains into the portal circulation, it seems necessary to distinguish between the two in evaluating the metabolic consequences of excessive intraabdominal fat.

The results of our study, using the recently validated MRI 


\begin{tabular}{|c|c|c|c|c|c|c|c|c|}
\hline & BMI & $\begin{array}{l}\text { W/H } \\
\text { ratio }\end{array}$ & $\begin{array}{c}\text { Total } \\
\text { body } \\
\text { fat mass }\end{array}$ & $\begin{array}{c}\text { Subcutaneous } \\
\text { abdominal } \\
\text { fat mass }\end{array}$ & $\begin{array}{c}\text { Intra- } \\
\text { peritoneal } \\
\text { fat mass }\end{array}$ & $\begin{array}{c}\text { Retro- } \\
\text { peritoneal } \\
\text { fat mass }\end{array}$ & $\begin{array}{l}\text { Sum of } \\
\text { truncal } \\
\text { skinfolds }\end{array}$ & $\begin{array}{l}\text { Sum of } \\
\text { peripheral } \\
\text { skinfolds }\end{array}$ \\
\hline & $\mathrm{kg} / \mathrm{m}^{2}$ & & \multicolumn{4}{|c|}{ percentage of total body mass } & \multicolumn{2}{|c|}{$m m$} \\
\hline BMI $\left(\mathrm{kg} / \mathrm{m}^{2}\right)$ & 1 & & & & & & & \\
\hline W/H ratio & $0.44^{*}$ & 1 & & & & & & \\
\hline Total body fat mass (percentage of total body mass) & $0.88^{\ddagger}$ & $0.61^{\ddagger}$ & 1 & & & & & \\
\hline Subcutaneous abdominal fat mass (percentage of total body mass) & $0.72^{\ddagger}$ & 0.31 & $0.71^{\ddagger}$ & 1 & & & & \\
\hline Intraperitoneal fat mass (percentage of total body mass) & $0.47^{*}$ & $0.64^{\ddagger}$ & $0.65^{\ddagger}$ & $0.55^{\ddagger}$ & 1 & & & \\
\hline Retroperitoneal fat mass (percentage of total body mass) & -0.01 & $0.48 *$ & 0.28 & 0.03 & $0.45 *$ & 1 & & \\
\hline Sum of truncal skinfolds (mm) & $0.94^{\ddagger}$ & $0.50^{*}$ & $0.86^{\ddagger}$ & $0.84^{\ddagger}$ & $0.45^{*}$ & 0.05 & 1 & \\
\hline Sum of peripheral skinfolds (mm) & $0.88^{\ddagger}$ & $0.35^{8}$ & $0.84^{\ddagger}$ & $0.69^{\ddagger}$ & $0.36^{8}$ & 0.03 & $0.87^{\ddagger}$ & 1 \\
\hline
\end{tabular}

${ }^{8} P<0.05, * P<0.01$, and ${ }^{\ddagger} P<0.001$.

method to measure the amount of fat in different abdominal adipose tissue compartments (32), provide new information on the interrelations among these compartments with increasing adiposity. Several comments about the interrelations among different adipose tissue compartments seem in order. First, in middle-aged men, the fat mass in each abdominal compartment, as well as the total abdominal fat mass, increased proportionally with total body fat mass (Fig. 1). Second, on the average, only about one-third of total body fat was located in the abdominal region. Third, intraperitoneal fat mass correlated positively with subcutaneous abdominal fat mass, but the former averaged about one-half the latter (Fig. 3 ) or $\sim 10 \%$ of the total body fat mass. It might be noted that relatively few individuals in the present cohort had unusually high accumulations of intraperitoneal fat relative to total body fat (Fig. 1) or to subcutaneous abdominal fat (Fig. 2). These observations cast doubt on the concept that for middle-aged men most excess body fat commonly accumulates inside the abdomen; if individuals of this type exist, they were not represented in the current cohort.

The retroperitoneal fat was an even smaller compartment than the intraperitoneal fat and changed less with increasing body fat than did the other abdominal compartments. A few recent studies using computerized tomography $(60,61)$ and MRI techniques (62) estimated that the intraperitoneal and retroperitoneal adipose tissues represented $72-82$ and 18-28\%, respectively, of the total intraabdominal adipose tissue volume in men. In a recent study from our group (32), the intraperitoneal and retroperitoneal adipose tissue masses measured after dissection in three cadavers were $67-71$ and $29-33 \%$, respectively, of the intraabdominal adipose tissue mass. More importantly, the current study suggests that the relative amounts of these two intraabdominal depots depend on the degree of obesity. For example, in the lean group, the intraperitoneal and retroperitoneal adipose tissue masses were 58 and $42 \%$ of the

Table IV. Euglycemic, Hyperinsulinemic Glucose Clamp Study Data

\begin{tabular}{|c|c|c|c|c|}
\hline & Lean group & Intermediate group & Obese group & $P$ value* \\
\hline \multicolumn{5}{|l|}{ Plasma glucose (mmol/liter) } \\
\hline Fasting & $5.4 \pm 0.5$ & $5.4 \pm 0.8$ & $5.5 \pm 0.6$ & 0.93 \\
\hline Low-dose insulin infusion & $5.3 \pm 0.4$ & $5.3 \pm 0.5$ & $5.4 \pm 0.5$ & 0.88 \\
\hline High-dose insulin infusion & $5.2 \pm 0.2$ & $5.2 \pm 0.5$ & $5.3 \pm 0.4$ & 0.69 \\
\hline \multicolumn{5}{|l|}{ Plasma insulin (pmol/liter) } \\
\hline Fasting & $79 \pm 35$ & $124 \pm 69$ & $190 \pm 123^{\ddagger}$ & 0.007 \\
\hline Low-dose insulin infusion & $337 \pm 65$ & $376 \pm 95$ & $413 \pm 152$ & 0.29 \\
\hline High-dose insulin infusion & $553 \pm 114$ & $541 \pm 122$ & $611 \pm 198$ & 0.45 \\
\hline \multicolumn{5}{|c|}{$R_{\mathrm{d}}$ values (rate of glucose disposal in $\mathrm{mg} / \mathrm{min} / \mathrm{kg}$ of lean body mass) } \\
\hline Low-dose insulin infusion & $4.93 \pm 1.6$ & $4.05 \pm 1.6$ & $3.09 \pm 1.0^{\ddagger}$ & 0.017 \\
\hline High-dose insulin infusion & $8.88 \pm 2.8$ & $7.79 \pm 2.5$ & $4.85 \pm 1.8^{\ddagger 8}$ & 0.0004 \\
\hline \multicolumn{5}{|c|}{$\mathrm{HGO}(\mathrm{mg} / \mathrm{min} / \mathrm{kg}$ of lean body mass) } \\
\hline Fasting & $2.41 \pm 0.7(2.72)$ & $2.10 \pm 0.5(2.22)$ & $1.87 \pm 0.4 \quad(1.83)$ & 0.07 \\
\hline Low-dose insulin infusion & $0.54 \pm 0.6(0.25)$ & $0.52 \pm 0.5(0.56)$ & $0.77 \pm 0.6 \quad(0.83)$ & 0.42 \\
\hline High-dose insulin infusion & $0.06 \pm 0.2(0.0)$ & $0.16 \pm 0.3(0.0)$ & $0.37 \pm 0.5^{\| \prime}(0.29)$ & 0.02 \\
\hline
\end{tabular}

Data are presented as mean $\pm \mathrm{SD}$. Median values for $\mathrm{HGO}$ are given in parentheses. ${ }^{*} P$ values are from ANOVA or Kruskal Wallis test for the skewed data. Fasting values are the mean of $\mathbf{- 4 0}$ to $0 \mathrm{~min}$ values before the insulin infusion; low-dose and high-dose insulin infusion values represent the means of 80-120 and 170-210 min, respectively. ${ }^{\ddagger} P<0.01$, " $P<0.02$ vs. lean group (Bonferroni-adjusted); ${ }^{8} P<0.01$ vs. intermediate group (Bonferroni-adjusted). 



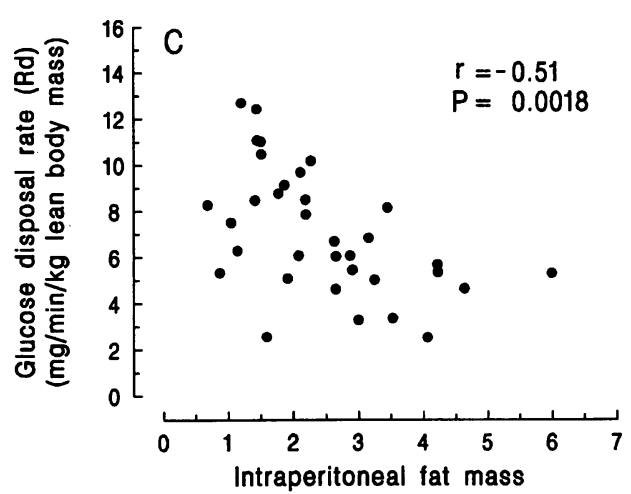

(\% of body mass)

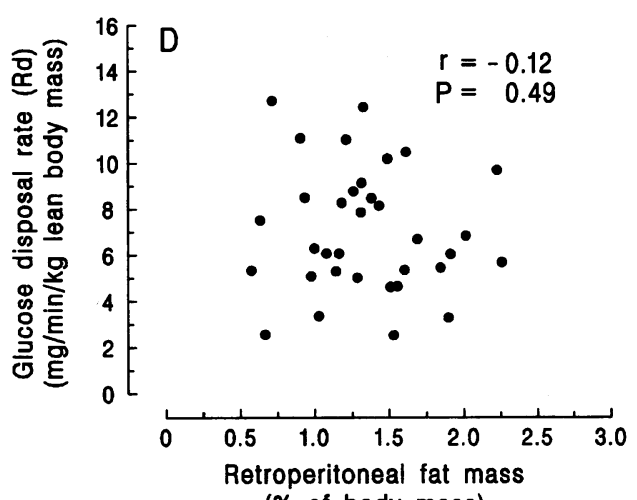

(\% of body mass)
Figure 3. The relationships of insulin-mediated glucose disposal rate $\left(R_{\mathrm{d}}\right.$ value, during euglycemic, hyperinsulinemic glucose clamp study at $40 \mathrm{mU} / \mathrm{m}^{2} \cdot \min$ insulin infusion rate) and total body $(A)$, subcutaneous abdominal $(B)$, intraperitoneal $(C)$, and retroperitoneal $(D)$ fat masses. Pearson product-moment analysis was used for computing the correlation coefficients $(r)$ after $\log$ transformation of both dependent and independent variables. intraabdominal adipose tissue mass, respectively; in the intermediate group they were 66 and 34\%, respectively; and in the obese group they were 69 and $31 \%$, respectively. The range of intraperitoneal adipose tissue mass varied from 37 to $84 \%$ of the total intraabdominal adipose tissue mass. This large variability seems to be mainly due to the small increase in retroperitoneal adipose tissue mass with increasing obesity; it is possible that anatomic factors as well as reduced metabolic activity of the retroperitoneal adipose tissue may limit its increase in size.

The data from the euglycemic, hyperinsulinemic, glucose clamp studies revealed a highly significant inverse correlation between $R_{\mathrm{d}}$ values and total body fat mass (expressed as percentage of total body mass). For the group as a whole, the percent body fat explained $\sim 37 \%$ of the variation in the $R_{\mathrm{d}}$ values $(r=-0.61)$ similar to the observations of others (6365 ). In addition, visual inspection of the data (Fig. $3 A$ ) reveals that, compared with the lean, the obese subjects had lower $R_{\mathrm{d}}$ values with less variation, suggesting a dominant role of increasing obesity in determining a subject's insulin sensitivity. Of interest, the effects of increasing total body fat on $R_{\mathrm{d}}$ values appeared to reach a maximum at a body fat content of $\sim 30 \%$ of body mass. A similar finding was noted by Bogardus et al. (63) for Pima Indians. Regardless, these studies show that variation in total body fat cannot explain all the variance in insulin-mediated glucose disposal. Therefore, other factors, such as regional adiposity $(66,67)$, degree of physical activity $(68,69)$, and genetic predisposition $(70)$ may be implicated as

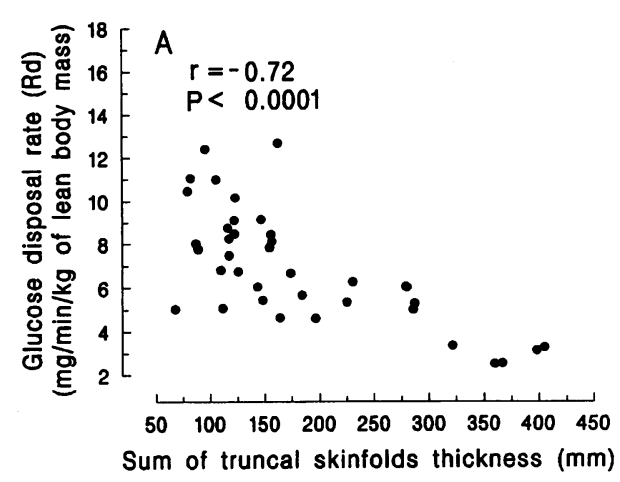

$B$

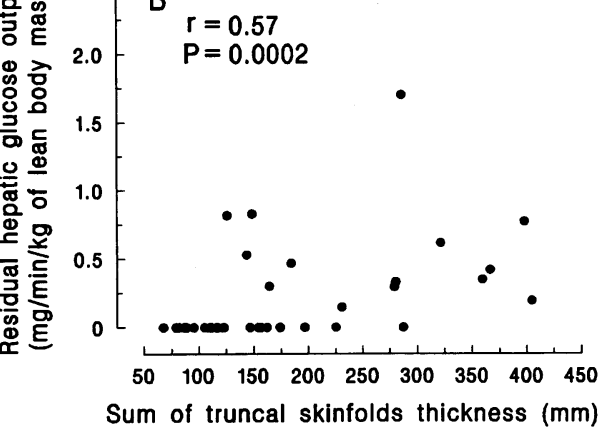

Figure 4. The relationships of the sum of truncal skinfold thickness ( subscapular, mid-axillary, chest, abdominal, and suprailiac) and insulin-mediated glucose disposal rate $\left(R_{\mathrm{d}}\right)(A)$ and rHGO $(B)$ during euglycemic, hyperinsulinemic glucose clamp study at $40 \mathrm{mU} /$ $\mathrm{m}^{2} \cdot \mathrm{min}$ insulin infusion rate. Pearson product-moment analysis was used for computing the correlation coefficient between truncal skinfold thickness and $R_{\mathrm{d}}$ after $\log$ transformation of both dependent and independent variables. Spearman rank correlation analysis was used for computing the correlation coefficient between truncal skinfold thickness and rHGO. 
Table V. Correlation between Various Adipose Tissue Compartments and $R_{d}$ Values (Glucose Disposal Rate) during High-dose Insulin Infusion, before and after Adjustment for Total Body Fat (Percentage of Total Body Mass)

\begin{tabular}{|c|c|c|c|c|}
\hline \multirow[b]{2}{*}{ Independent variable } & \multicolumn{2}{|c|}{ Univariate correlation } & \multicolumn{2}{|c|}{$\begin{array}{c}\text { Partial correlation } \\
\text { (adjusted for total body fat) }\end{array}$} \\
\hline & $r$ & $P$ value & $r$ & $P$ value \\
\hline Subcutaneous abdominal fat (percentage of total body mass) & -0.62 & $<0.0001$ & -0.33 & 0.06 \\
\hline Intraperitoneal fat (percentage of total body mass) & -0.51 & 0.002 & -0.19 & 0.29 \\
\hline Retroperitoneal fat (percentage of total body mass) & -0.12 & 0.49 & +0.07 & 0.7 \\
\hline Subcutaneous abdominal plus intraperitoneal fat (percentage of total body mass) & -0.65 & $<0.0001$ & -0.35 & 0.05 \\
\hline Sum of truncal skinfold thickness (mm) & -0.72 & $<0.0001$ & -0.40 & 0.01 \\
\hline Sum of peripheral skinfold thickness (mm) & -0.56 & 0.0003 & -0.09 & 0.6 \\
\hline W/H ratio & -0.52 & 0.003 & -0.13 & 0.5 \\
\hline
\end{tabular}

$r$ indicates Pearson product-moment correlation coefficient.

well. To date, however, the quantitative influence of regional adiposity beyond that of overall adiposity has not been accurately defined.

In our study, intraperitoneal fat mass was significantly and inversely correlated with $R_{\mathrm{d}}$ values; however, the correlation coefficient for this link $(r=-0.51)$ was lower than that for the total body fat and $R_{\mathrm{d}}$ values $(r=-0.61$ ). Furthermore, on the average, intraperitoneal fat mass was only $\sim 10 \%$ of the total body fat mass. Therefore, even if intraperitoneal adipose tissue was more metabolically active than other types of adipose tissue, its contribution to total FFA flux nonetheless should be relatively small. Thus, in this light, it is perhaps not surprising that intraperitoneal fat did not appear to have a unique impact on peripheral insulin sensitivity.

Interestingly, retroperitoneal adipose tissue mass showed no relationship with either $R_{\mathrm{d}}$ or rHGO values. These findings suggest that retroperitoneal fat may be relatively less metabolically active than abdominal subcutaneous and intraperitoneal fat. In support of this contention, in vitro studies have shown markedly higher rates of catecholamine-induced lipolysis in omental and mesenteric adipocytes than in retroperitoneal adipocytes in nonobese and severely obese men and in severely obese women, but such differences were not observed in nonobese women $(71,72)$. On the other hand, no differences in lipoprotein lipase activity and lipid uptake between omental and retroperitoneal adipose tissue have been reported (60). Overall, however, it appears that retroperitoneal adipose tissue, because of its small size and possibly lower metabolic activity, is not a major contributor to the metabolic complications of obesity.

The subcutaneous fat of the trunk, on the other hand, makes

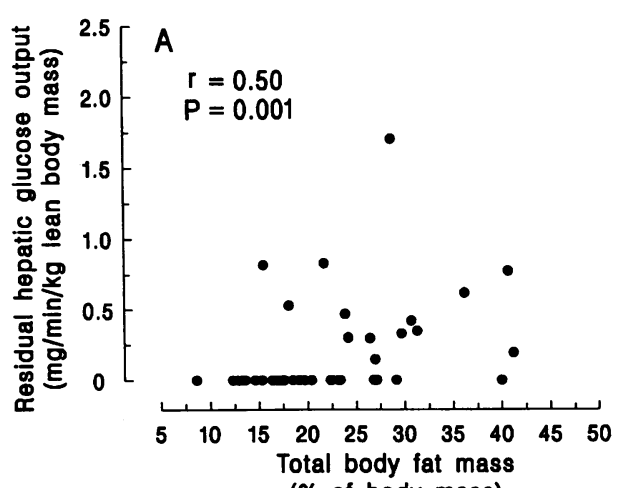

(\% of body mass)

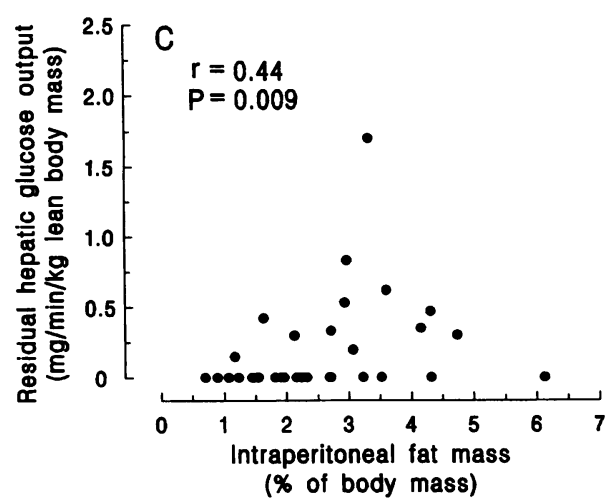

(\% of body mass)
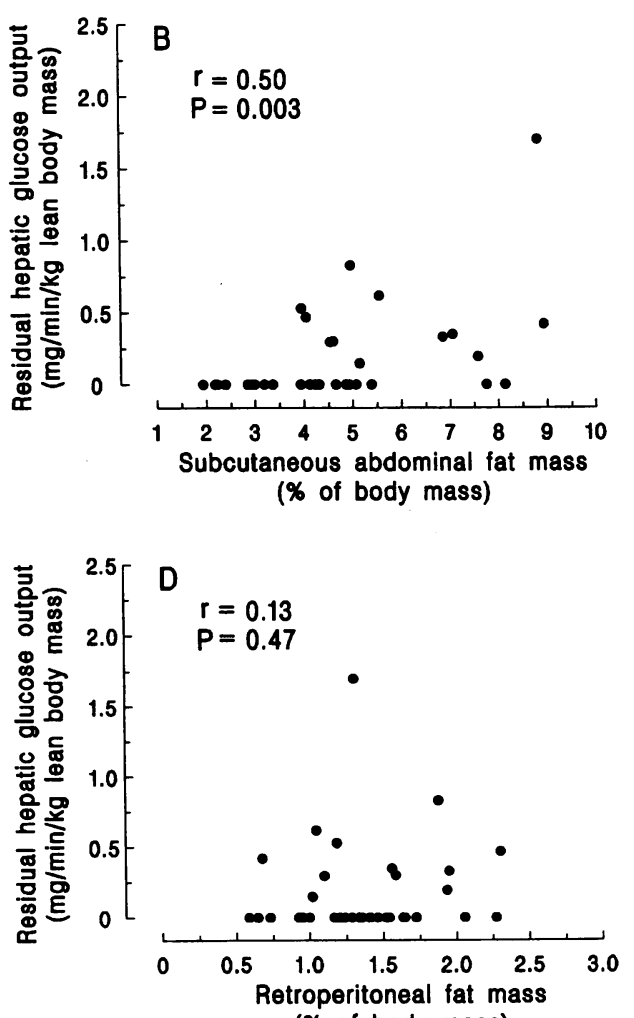

Figure 5. The relationships of rHGO (during euglycemic, hyperinsulinemic glucose clamp study at $40 \mathrm{mU} / \mathrm{m}^{2} \cdot \mathrm{min}$ insulin infusion rate) and total body $(A)$, subcutaneous abdominal $(B)$, intraperitoneal $(C)$, and retroperitoneal $(D)$ fat masses. $r$ indicates Spearman rank correlation coef(\% of body mass) ficient. 
Table VI. Correlation between Various Adipose Tissue Compartments and Residual HGO during High-dose Insulin Infusion, before and after Adjustment for Total Body Fat (Percentage of Total Body Mass)

\begin{tabular}{|c|c|c|c|c|}
\hline \multirow[b]{2}{*}{ Independent variable } & \multicolumn{2}{|c|}{ Univariate correlation } & \multicolumn{2}{|c|}{$\begin{array}{c}\text { Partial correlation } \\
\text { (adjusted for total body fat) }\end{array}$} \\
\hline & $r$ & $P$ value & $r$ & $P$ value \\
\hline Subcutaneous abdominal fat (percentage of total body mass) & +0.50 & 0.003 & +0.23 & 0.2 \\
\hline Intraperitoneal fat (percentage of total body mass) & +0.44 & 0.009 & +0.18 & 0.33 \\
\hline Retroperitoneal fat (percentage of total body mass) & +0.13 & 0.47 & -0.04 & 0.83 \\
\hline Subcutaneous abdominal plus intraperitoneal fat (percentage of total body mass) & +0.58 & 0.003 & +0.36 & 0.04 \\
\hline Sum of truncal skinfold thickness (mm) & +0.57 & 0.0002 & +0.33 & 0.04 \\
\hline Sum of peripheral skinfold thickness $(\mathrm{mm})$ & +0.39 & 0.02 & -0.02 & 0.9 \\
\hline $\mathrm{W} / \mathrm{H}$ ratio & +0.39 & 0.03 & +0.02 & 0.9 \\
\hline
\end{tabular}

$r$ indicates Spearman rank correlation coefficient.

up a greater proportion of total fat than does intraperitoneal fat. Indeed, subcutaneous abdominal fat mass itself is about twice that of intraperitoneal fat (Table II). Moreover, the amount of subcutaneous abdominal fat correlated better with $R_{\mathrm{d}}$ values than did intraperitoneal fat (Fig. $3 B$ ). A still stronger correlation was found between the sum of truncal skinfold thickness and $R_{\mathrm{d}}$ values (Fig. $4 A$ ). The total truncal subcutaneous fat, therefore, may constitute the single most active compartment of adipose tissue affecting insulin-mediated glucose disposal. Certainly its size alone could impart the greater influence on insulin sensitivity.

We also used another approach to determine whether various adipose tissue compartments independently affect $R_{\mathrm{d}}$ values beyond total body fat mass; this was to estimate partial correlation coefficients after adjusting for total body fat. If all the adipose tissue compartments were equal in their metabolic activity, none of them should reveal an additional effect beyond that of total body fat. With this approach, intraperitoneal fat mass was not found to have an independent effect on $R_{\mathrm{d}}$ values (Table V), whereas subcutaneous abdominal fat had a partial correlation coefficient of -0.33 which approached statistical significance $(P=0.06)$. Combining the subcutaneous abdominal and intraperitoneal fat resulted in a significant correlation (partial $r=-0.35, P=0.05$ ); this finding is consistent with the concept that the total amount of intraperitoneal and subcutaneous abdominal fat contributes more to insulin resistance than does the total fat mass throughout the body. An even higher partial correlation was obtained for the sum of truncal skinfold thickness, a measure of subcutaneous truncal adipose tissue, of which subcutaneous abdominal adipose tissue is a part.

Our study further revealed interesting results regarding the relationships of total and regional body fat masses with hepatic insulin sensitivity. For example, increasing overall obesity was accompanied by a reduction in insulin-induced suppression of HGO. The hepatic insulin sensitivity, however, was not more strongly correlated with the mass of intraperitoneal fat than with the total body fat mass; and once again, the best relationship was found with the sum of truncal skinfold thickness. It therefore did not appear that intraperitoneal fat mass was the only factor responsible for the failure to suppress HGO in obese patients.

The data obtained in this study support the concept that subcutaneous adipose tissue in the truncal region, including thorax and abdomen, contributes more to insulin resistanceboth in the whole body and in the liver-than does adipose tissue elsewhere in the body. This finding supports previous reports that truncal obesity predisposes to insulin resistance (11-13) and $\operatorname{NIDDM}(14,15,17,19)$. On the other hand, our investigation failed to demonstrate that intraperitoneal fat uniquely enhances insulin resistance.

It must be mentioned, however, that we have not explored the full range of variation in body fat distribution in men. It remains possible that some individuals may uniquely accumulate large amounts of fat inside the abdomen and not elsewhere. In this study, we did not identify otherwise lean men with selective intraperitoneal obesity, although the literature suggests that such men exist $(58,73)$. If so, they might be unusually susceptible to develop insulin resistance and NIDDM. Moreover, we did not study women; there may be a greater variability in body fat distribution in women than in men, and women having intraperitoneal obesity may be more likely to be insulin resistant than those in whom body fat is largely in the gluteofemoral region. Although our study was not designed to address the issue of changes in body composition and its relationship with insulin sensitivity with age and ethnicity, these variables did not affect our conclusions.

Finally, on the basis of this investigation, we suggest that subcutaneous truncal obesity, which can be estimated by skinfold thickness, yields a parameter that has a high degree of relationship with peripheral and hepatic insulin sensitivity. Our data further suggest that subcutaneous truncal obesity is more influential in determining insulin resistance than is subcutaneous obesity in the extremities. Further, the current results seem to downplay the uniqueness of intraperitoneal fat in the causation of insulin resistance; in a word, our findings change the focus of fat distribution-insulin resistance relationship from intraperitoneal fat to subcutaneous truncal fat.

\section{Acknowledgments}

The authors express appreciation for the excellent technical assistance of Margaret Arnecke, Keith Lowther, and Jerry Payne. The assistance of Marjorie Whelan and the nursing and dietetic services of the General Clinical Research Center is gratefully acknowledged. Kay McCorkle, Lovie Peace, and Marge Haney in the laboratory of Dr. Roger H. Unger assisted with insulin radioimmunoassays. Beverley Adams-Huet, biostatistician of the General Clinical Research Center, assisted in the analysis of the data.

This work was supported by National Institutes of Health grants HL-29252, DK-42582, DK-02700, and MO1-RR-00633 (NIH/DHS/ DHHS ), unrestricted grants from Merck, and Bristol-Myers-Squibb, the 
Southwestern Medical Foundation, and the Moss Heart Foundation, Dallas, TX.

\section{References}

1. Manson, J. E., G. A. Colditz, M. J. Stampfer, W. C. Willett, B. Rosner, R. R. Monson, F. E. Speizer, and C. H. Hennekens. 1990. A prospective study of obesity and risk of coronary heart disease in women. N. Engl. J. Med. 322:882889.

2. Hubert, H. B., M. Fenileib, P. M. McNamara, and W. P. Castelli. 1983 Obesity as an independent risk factor for cardiovascular disease: a 26-year followup of participants in the Framingham heart study. Circulation. 67:968-977.

3. Chapman, J. M., A. H. Coulson, V. A. Clark, and E. R. Borun. 1971. The differential effect of serum cholesterol, blood pressure and weight on the incidence of myocardial infarction and angina pectoris. J. Chronic Dis. 23:631-645.

4. van Itallie, T. B. 1985. Health implications of overweight and obesity in the United States. Ann. Intern. Med. 103:983-988.

5. Knowler, W. C., D. J. Pettitt, P. J. Savage, and P. H. Bennett. 1981. Diabetes incidence in Pima indians: contributions of obesity and parental diabetes. Am. J. Epidemiol. 113:144-156.

6. Westlund, K., and R. Nicolaysen. 1972. Ten-year mortality and morbidity related to serum cholesterol. A follow-up of 3,751 men aged 40-49. Scand. J. Clin. Lab. Invest. 127(Suppl. X):1-24.

7. Haffner, S. M., M. P. Stern, B. D. Mitchell, H. P. Hazuda, and J. K. Patterson. 1990. Incidence of type II diabetes in Mexican Americans predicted by fasting insulin and glucose levels, obesity, and body-fat distribution. Diabetes. 39:283-288.

8. Zavaroni, I., E. Bonora, M. Pagliara, E. Dall'Aglio, L. Luchetti, G. Buonanno, P. A. Bonati, M. Bergonzani, L. Gnudi, M. Passeri, and G. M. Reaven. 1989. Risk factors for coronary artery disease in healthy persons with hyperinsulinemia and normal glucose tolerance. N. Engl. J. Med. 320:702-706.

9. Ferrannini, E., S. M. Haffner, B. D. Mitchell, and M. P. Stern. 1991. Hyperinsulinemia: the key feature of a cardiovascular and metabolic syndrome. Diabetologia. 34:416-422.

10. Vague, J. 1956. The degree of masculine differentiation of obesities: a factor determining predisposition to diabetes, atherosclerosis, gout, and uric calculous disease. Am. J. Clin. Nutr. 4:20-34.

11. Kissebah, A. H., N. Vydelingum, R. Murray, P. J. Evans, A. J. Hartz, R. K. Kalkhoff, and P. W. Adams. 1982. Relation of body fat distribution to metabolic complications of obesity. J. Clin. Endocrinol. \& Metab. 54:254-260.

12. Krotkiewski, M., P. Bjorntorp, L. Sjostrom, and U. Smith. 1983. Impact of obesity on metabolism in men and women. Importance of regional adipose tissue distribution. J. Clin. Invest. 72:1150-1162.

13. Evans, D. J., R. G. Hoffmann, R. K. Kalkhoff, and A. H. Kissebah. 1984. Relationship of body fat topography to insulin sensitivity and metabolic profiles in premenopausal women. Metab. Clin. Exp. 33:68-75.

14. Hartz, A. J., D. C. Rupley, and A. A. Rimm. 1984. The association of girth measurements with disease in 32,856 women. Am. J. Epidemiol. 119:7180.

15. Larsson, B., J. Seidell, K. Svardsudd, L. Welin, G. Tibblin, L. Wilhelmsen, and P. Bjorntorp. 1989. Obesity, adipose tissue distribution and health in menthe study of men born in 1913. Appetite. 13:37-44.

16. Despres, J. P., S. Moorjani, M. Ferland, A. Tremblay, P. J. Lupien, A. Nadeau, S. Pinault, G. Theriault, and C. Bouchard. 1989. Adipose tissue distribution and plasma lipoprotein levels in obese women. Importance of intra-abdominal fat. Arteriosclerosis. 9:203-210.

17. Haffner, S. M., M. P. Stern, H. P. Hazuda, J. Pugh, and J. K. Patterson. 1987. Do upper-body and centralized adiposity measure different aspects of regional body-fat distribution? Relationship to non-insulin-dependent diabetes mellitus, lipids, and lipoproteins. Diabetes. 36:43-51.

18. Lapidus, L., C. Bengtsson, B. Larsson, K. Pennert, E. Rybo, and L. Sjostrom. 1984. Distribution of adipose tissue and risk of cardiovascular disease and death: a 12-year follow-up of participants in the population study of women in Gothenburg. Br. Med. J. 289:1257-1261.

19. Ohlson, L. O., B. Larsson, K. Svardsudd, L. Welin, H. Eriksson, L. Wilhelmsen, P. Bjorntorp, and G. Tibblin. 1985. The influence of body fat distribution on the incidence of diabetes mellitus. 13.5 years of follow-up of the participants in the study of men born in 1913. Diabetes. 34:1055-1058.

20. Ducimetiere, P., J. Richard, and F. Cambien. 1986. The pattern of subcutaneous fat distribution in middle-aged men and the risk of coronary heart disease: the Paris Prospective Study. Int. J. Obes. 10:229-240.

21. Casassus, P., A. Fontbonne, N. Thibult, P. Ducimetiere, J. L. Richard, J. R. Claude, J. M. Warnet, G. Rosselin, and E. Eschwege. 1992. Upper-body fat distribution: a hyperinsulinemia-independent predictor of coronary heart disease mortality. The Paris Prospective Study. Arterioscler. Thromb. 12:1387-1392.

22. Donahue, R. P., R. D. Abbott, E. Bloom, D. M. Reed, and K. Yano. 1987. Central obesity and coronary heart disease in men. Lancet. 1:821-824.

23. Welin, L., K. Svardsudd, L. Wilhelmsen, B. Larsson, and G. Tibblin. 1987. Analysis of risk factors for stroke in a cohort of men born in 1913. $N$. Engl. J. Med. 317:521-526.
24. Carlson, L. A., D. Hallberg, and H. Micheli. 1969. Quantitative studies on the lipolytic response of human subcutaneous and omental adipose tissue to noradrenaline and theophylline. Acta Med. Scand. 185:465-469.

25. Richelsen, B., S. B. Pedersen, T. Moller-Pedersen, and J. F. Bak. 1991 Regional differences in triglyceride breakdown in human adipose tissue: effects of catecholamines, insulin, and prostaglandin E2. Metab. Clin. Exp. 40:990-996.

26. Landin, K., P. Lonnroth, M. Krotkiewski, G. Holm, and U. Smith. 1990 Increased insulin resistance and fat cell lipolysis in obese but not lean women with high waist/hip ratio. Eur. J. Clin. Invest. 20:530-535.

27. Rebuffe-Scrive, M., L. Enk, N. Crona, P. Lonnroth, L. Abrahamsson, U. Smith, and P. Bjorntorp. 1985. Fat cell metabolism in different regions in women. Effects of menstrual cycle, pregnancy, and lactation. J. Clin. Invest. 75:19731976.

28. Ostman, J., P. Arner, P. Engfeldt, and L. Kager. 1979. Regional differences in the control of lipolysis in human adipose tissue. Metab. Clin. Exp. 28:11981205.

29. Efendic, S. 1970. Catecholamines and metabolism of human adipose tissue. III. Comparison between the regulation of lipolysis in omental and subcutaneous adipose tissue. Acta Med. Scand. 187:477-483.

30. Lafontan, M., L. Dong-Tran, and M. Berlan. 1979. Alpha-adrenergic antilipolytic effect of adrenaline in human fat cells of the thigh: comparison with adrenaline responsiveness of different fat deposits. Eur. J. Clin. Invest. 9:261266.

31. Bjorntorp, P. 1990. "Portal" adipose tissue as a generator of risk factors for cardiovascular disease and diabetes. Arteriosclerosis. 10:493-496.

32. Abate, N., D. Burns, R. M. Peshock, A. Garg, and S. M. Grundy. 1994. Estimation of adipose tissue mass by magnetic resonance imaging: validation against dissection in human cadavers. J. Lipid Res. 35:1490-1496.

33. Siri, W. E. 1961. Body composition from fluid spaces and density. In Techniques for Measuring Body Composition. J. Brozek and A. Hanschel, editors. National Academy of Sciences, Washington, DC. 223-224.

34. Thomas, L. W. 1962. The chemical composition of adipose tissue of man and mice. O. J. Exp. Physiol. 47:179-188.

35. DeFronzo, R. A., J. D. Tobin, and R. Andres. 1979. Glucose clamp technique: a method for quantifying insulin secretion and resistance. Am. J. Physiol. 233:E214-E223.

36. Finegood, D. T., R. N. Bergman, and M. Vranic. 1987. Estimation of endogenous glucose production during hyperinsulinemic-euglycemic glucose clamps. Comparison of unlabeled and labeled exogenous glucose infusates. Diabetes. 36:914-924.

37. Steele, R. 1959. Influence of glucose loading and of injected insulin on hepatic glucose output. Ann. NY Acad. Sci. 82:420-430.

38. Insel, P. A, J. E. Liljenquist, J. D. Tobin, R. S. Shewin, P. Watkins, R. Andres, and M. Berman. 1975. Insulin control of glucose metabolism in man: a new kinetic analysis. J. Clin. Invest. 55:1057-1066.

39. Meneilly, G. S., D. Elahi, K. L. Minaker, and J. W. Rowe. 1987. Somatostatin does not alter insulin-mediated glucose disposal. J. Clin. Endocrinol. \& Metab. 65:364-370.

40. Herbert, V., K. Lau, C. W. Gottlieb, and S. J. Bleicher. 1965. Coated charcoal immunoassay of insulin. J. Clin. Endocrinol. \& Metab. 25:1375-1384.

41. Yalow, R. S., and S. A. Berson. 1960. Immunoassay of endogenous plasma insulin in man. J. Clin. Invest. 39:1157-1175.

42. The Lipid Research Clinics Population Studies Data Book. 1979. Volume 1: The Prevalence study. U.S. Department of Health, Education, and Welfare; Public Health Service; National Institute of Health. Publication No. 79-1527.

43. National Diabetes Data Group. 1979. Classification and diagnosis of diabetes mellitus and other categories of glucose tolerance. Diabetes. 28:1039-1057.

44. Randle, P. J., P. B. Garland, C. N. Hales, and E. A. Newsholme. 1963. The glucose-fatty acid cycle. Its role in insulin sensitivity and the metabolic disturbances of diabetes mellitus. Lancet. I:785-789.

45. Ferrannini, E., E. J. Barrett, S. Bevilacqua, and R. A. DeFronzo. 1983. Effect of fatty acids on glucose production and utilization in man. J. Clin. Invest. 72:1737-1747.

46. Crespin, S. R., W. B. Greenough III, and D. Steinberg. 1973. Stimulation of insulin secretion by long-chain free fatty acids: a direct pancreatic effect. $J$. Clin. Invest. 52:1979-1984.

47. Svedberg, J., G. Stromblad, A. Wirth, U. Smith, and P. Bjorntorp. 1991. Fatty acids in the portal vein of the rat regulate hepatic insulin clearance. J. Clin. Invest. 88:2054-2058.

48. Opie, L. H., and P. G. Walfish. 1963. Plasma free fatty acid concentration in obesity. N. Engl. J. Med. 268:757-760.

49. Golay, A., J. P. Felber, H. U. Meyer, B. Curchod, E. Maeder, and E. Jequier. 1984. Study on lipid metabolism in obesity diabetes. Metab. Clin. Exp. 33:111-116.

50. Golay, A., A. L. Swislocki, Y. D. Chen, J. B. Jaspan, and G. M. Reaven. 1986. Effect of obesity on ambient plasma glucose, free fatty acid, insulin, growth hormone, and glucagon concentrations. J. Clin. Endocrinol. \& Metab. 63:481 484.

51. Dole, V. P. 1956. The relations between nonesterified fatty acids in plasma and the metabolism of glucose. J. Clin. Invest. 35:150-154. 
52. Gordon, T., and W. B. Kammell. 1973. The effects of overweight on cardiovascular diseases. Geriatrics. 28:80-88.

53. Bjorntorp, P. 1985. Obesity and the risk of cardiovascular disease. Ann. Clin. Res. 17:3-9.

54. Bouchard, C., J. P. Despres, and P. Mauriege. 1993. Genetic and nongenetic determinants of regional fat distribution. Endocr. Rev. 14:72-93.

55. Jensen, M. D., M. W. Haymond, R. A. Rizza, P. E. Cryer, and J. M. Miles. 1989. Influence of body fat distribution on free fatty acid metabolism in obesity. J. Clin. Invest. 83:1168-1173.

56. van der Kooy, K., R. Leenen, J. C. Seidell, P. Deurenberg, A. Droop, and C. J. G. Bakker. 1993. Waist-hip ratio is a poor predictor of changes in visceral fat. Am. J. Clin. Nutr. 57:327-333.

57. Sparrow, D., G. A. Borkan, S. G. Gerzof, C. Wisniewski, and C. K. Silbert. 1986. Relationship of fat distribution to glucose tolerance. Results of computed tomography in male participants of the Normative Aging Study. Diabetes. 35:411-415.

58. Fujioka, S., Y. Matsuzawa, K. Tokunaga, and S. Tarui. 1987. Contribution of intra-abdominal fat accumulation to the impairment of glucose and lipid metabolism in human obesity. Metab. Clin. Exp. 36:54-59.

59. Koester, R. S., G. R. Hunter, S. Snyder, M. A. Khaled, and L. L. Berland. 1992. Estimation of computerized tomography derived abdominal fat distribution. Int. J. Obes. 16:543-554.

60. Marin, P., B. Andersson, M. Ottosson, L. Olbe, B. Chowdhury, H. Kvist, G. Holm, L. Sjostrom, and P. Bjontorp. 1992. The morphology and metabolism of intraabdominal adipose tissue in men. Metab. Clin. Exp. 41:1242-1248.

61. Chowdhury, B., L. Sjostrom, M. Alpsten, J. Kostanty, H. Kvist, and R. Lofgren. 1994. A multicompartment body composition technique based on computerized tomography. Int. J. Obes. 18:219-234.

62. Ross, R., K. D. Shaw, J. Rissanen, Y. Martel, J. de Guise, and L. Avruch. 1994. Sex differences in lean and adipose tissue distribution by magnetic resonance imaging: anthropometric relationships. Am. J. Clin. Nutr. 59:1277-1285.

63. Bogardus, C., S. Lillioja, D. Mott, G. R. Reaven, A. Kashiwagi, and J. E. Foley. 1984. Relationship between obesity and maximal insulin-stimulated glucose uptake in vivo and in vitro in Pima Indians. J. Clin. Invest. 73:800-805.
64. Bogardus, C., S. Lillioja, D. M. Mott, C. Hollenbeck, and G. M. Reaven. 1985. Relationship between degree of obesity and in vivo insulin action in man Am. J. Physiol. 248:E286-E289.

65. Kohrt, W. M., J. P. Kirwan, M. A. Staten, R. E. Bourey, D. S. King, and J. O. Holloszy. 1993. Insulin resistance in aging is related to abdominal obesity. Diabetes. 42:273-281.

66. Evans, D. J., R. Murray, and A. H. Kissebah. 1984. Relationship between skeletal muscle insulin resistance, insulin-mediated glucose disposal, and insulin binding. Effects of obesity and body fat topography. J. Clin. Invest. 74:15151525.

67. Landin, K., P. Lonnroth, M. Krotkiewski, G. Holm, and U. Smith. 1990 Increased insulin resistance and fat cell lipolysis in obese but not lean women with a high waist/hip ratio. Eur. J. Clin. Invest. 20:530-535.

68. Sato, Y., A. Iguchi, and N. Sakamoto. 1984. Biochemical determination of training effects using insulin clamp technique. Horm. Metab. Res. 16:483486.

69. Bogardus, C., E. Ravussin, D. C. Robbins, R. R. Wolfe, E. S. Horton, and E. A. Sims. 1984. Effects of physical training and diet therapy on carbohydrate metabolism in patients with glucose intolerance and non-insulin-dependent diabetes mellitus. Diabetes. 33:311-318.

70. Lillioja, S., D. M. Mott, J. K. Zawadzki, A. A. Young, W. G. Abbott, W. C. Knowler, P. H. Bennett, P. Moll, and C. Bogardus. 1987. In vivo insulin action is a familial characteristic in nondiabetic Pima Indians. Diabetes. 36:1329_ 1335 .

71. Rebuffe-Scrive, M., B. Andersson, L. Olbe, and P. Bjorntorp. 1989. Metabolism of adipose tissue in intraabdominal depots of nonobese men and women Metab. Clin. Exp. 38:453-458.

72. Rebuffe-Scrive, M., B. Anderson, L. Olbe, and P. Bjorntorp. 1990. Metabolism of adipose tissue in intraabdominal depots in severely obese men and women. Metab. Clin. Exp. 39:1021-1025.

73. Despres, J. P., S. Moorjani, P. J. Lupian, A. Tremblay, A. Nadeau, and C. Bouchard. 1990. Regional distribution of body fat, plasma lipoproteins, and cardiovascular disease. Arteriosclerosis. 10:497-511. 